IP Periodica Polytechnica Civil Engineering

\author{
60(1), pp. 89 95.2016 \\ DOI: $10.3311 /$ PPci.7767 \\ Creative Commons Attribution (1) \\ RESEARCH ARTICLE
}

\section{Effect of Prewetted Pumice Aggregate Addition on Concrete Properties under Different Curing Conditions}

\author{
Nihat Kabay, Ahmet B. Kizilkanat, M. Mansur Tüfekçi
}

Received 17-10-2014, revised 07-03-2015, accepted 09-06-2015

\begin{abstract}
This study researches the effects of different curing conditions on the properties of high strength concrete containing presoaked pumice aggregate (PA). Fine normal weight aggregate is substituted by an equal volume of $1 \mathrm{~h}$ and $24 \mathrm{~h}$ presoaked PA at 50\% and $100 \%$ fractions and a total of five concrete mixtures were prepared. After kept in water, air and hot weather, the performance of concretes were evaluated by determining their physical and mechanical properties at 28 days. Hot weather was found to be the most detrimental condition where the highest strength drops were observed. Frost resistance of concretes was improved with the use of presoaked $P A$ at $50 \%$ replacement ratio. The use of presoaked PA also decreased the shrinkage values of concrete specimens. The results showed that the use of presoaked PA in high strength concrete at 50\% replacement ratio could contribute to concrete properties when exposed to inadequate curing conditions.
\end{abstract}

\section{Keywords}

Curing conditions · frost resistance $\cdot$ mechanical properties . pumice $\cdot$ shrinkage

\section{Nihat Kabay}

Department of Civil Engineering, Yıldız Technical University, Istanbul, Turkey e-mail: nkabay@yildiz.edu.tr

\section{Ahmet B. Kizilkanat}

Department of Civil Engineering, Yıldız Technical University, Istanbul, Turkey e-mail: bkkanat@yildiz.edu.tr

\section{Mansur Tüfekçi}

Department of Civil Engineering, Yıldız Technical University, Istanbul, Turkey e-mail: mtufekci@yildiz.edu.tr

\section{Introduction}

As cement hydration develops, the necessary water to continue hydration is partially obtained from the capillary pores. In concretes with water to cement ratio (w/c) below approximately 0.42 , there would be insufficient water to promote complete hydration of the Portland cement. In order to overcome this problem, it is necessary to supply additional water during curing [1, 2]. The placing of concrete must be followed by adequate curing in a suitable environment during the early stages of hardening [3]. Curing of concrete is important especially during the first hours after casting to maintain optimal conditions for cement hydration, for assuring required durability and strength of the hardened concrete [3, 5, 6]. Therefore, in order to maximize the degree of hydration of cement and to reduce early stage shrinkage cracking it is important to apply effective curing during an extended period of time. Insufficient external curing can produce an important drop in concrete's internal relative humidity and even interrupt the hydration process. The internal curing (IC) method was suggested to overcome this problem by supplying additional water during curing [7]. Philleo [7] suggested incorporating presoaked lightweight aggregate (LWA) in concrete to provide an internal source of water necessary to accommodate that consumed by cement hydration. Since then, a lot of research has been carried out in this area and LWAs [2, 3, 8- 16], super absorbent polymers [17-19] and recycled aggregates [20,21] were reported as appropriate IC agents. Bentz and Snyder [22] and Jensen and Hansen [17] proposed equations to determine and quantify the amount of water or LWA needed for IC. Detailed information about IC can be found in refs [7, 17, 22]. It has also been reported that the substitution of LWA by normal weight aggregates might reduce the shrinkage of concrete. Herrera et al. [8] and Browning et al. [14] found that a significant decrease in shrinkage of concrete can be achieved by using saturated LWA. After casting concrete, the environmental conditions and its curing significantly affects the properties of concrete. In this view, this study focused on the use of presoaked PA in high strength concrete to determine its effects on concrete properties when exposed to various environmental conditions. Therefore, concrete specimens that contain different amounts of presoaked 
PA were kept at three different conditions; under water, in air and in hot weather. The last two conditions were selected to simulate inadequate external curing and severe weather conditions respectively. Hardened concrete properties such as compressive strength, splitting tensile strength, ultrasonic pulse velocity, dynamic modulus of elasticity and total shrinkage were determined. In addition, concrete specimens were exposed to freeze-thaw (FT) cycles to assess their frost resistance.

\section{Experimental procedure}

\subsection{Materials and mixture design}

The materials used in this research include limestone coarse aggregate with a particle density of $2.75 \mathrm{~kg} / \mathrm{dm}^{3}$, natural river sand with a particle density of $2.61 \mathrm{~kg} / \mathrm{dm}^{3}$, PA, cement, and chemical admixture. PA had a particle size between $1-4 \mathrm{~mm}$ and was obtained from Nevşehir, Turkey. The $1 \mathrm{~h}$ and $24 \mathrm{~h}$ absorption of the PA was $22.5 \%$ and $32.5 \%$ respectively and the particle density corresponding to each saturation degree was 1.01 and $1.05 \mathrm{~kg} / \mathrm{dm}^{3}$ respectively. Particle size distributions of the aggregates are presented in Table 1 . The type of cement used in all concrete series was CEM I 42.5 R and its properties is listed in Table 2. A commercially available modified polycarboxylate polymer based superplasticizer was also used at a constant ratio (\%1.3 of cement by weight) in all mixes.

Tab. 1. Particle size distribution of the aggregates

\begin{tabular}{cccc}
\hline \multirow{2}{*}{ Sieve opening $(\mathrm{mm})$} & \multicolumn{3}{c}{ Cumulative passing (\%) } \\
\cline { 2 - 4 } & $\begin{array}{c}\text { Normal weight } \\
\text { coarse aggregate }\end{array}$ & $\begin{array}{c}\text { Pumice } \\
\text { aggregate }\end{array}$ & $\begin{array}{c}\text { Normal weight } \\
\text { fine aggregate }\end{array}$ \\
\hline 16 & 100 & 100 & 100 \\
11.2 & 73 & 100 & 100 \\
8 & 35 & 100 & 100 \\
4 & 0 & 98 & 100 \\
2 & 0 & 26 & 75 \\
1 & 0 & 0 & 50 \\
0.5 & 0 & 0 & 35 \\
0.25 & 0 & 0 & 15 \\
\hline
\end{tabular}

Before casting concrete, PA was dried in an oven at $100^{\circ} \mathrm{C}$. After cooling the PA at room temperature, they were soaked in water for $1 \mathrm{~h}$ and $24 \mathrm{~h}$ to obtain different amounts of presoak water. The PA was then spread on paper sheets to provide the evaporation of the excess water and to obtain surface dry conditions.

Five different concrete mixes with a constant cement content $\left(400 \mathrm{~kg} / \mathrm{m}^{3}\right)$, aggregate volume fraction $(70.6 \%)$ and $\mathrm{w} / \mathrm{c}$ ratio (0.4) were prepared. The amount of PA introduced represents $50 \%$ and $100 \%$ of the total volume of fine normal weight aggregates, replacing partially and completely the $1-4 \mathrm{~mm}$ fraction. The mix proportions and fresh properties of concrete mixtures are presented in Table 3. In Table 3, $\mathrm{R}$ represents the reference concrete without PA. The other mixtures were coded in the form of PXX-YY; in which "P" represents the use of PA, "XX" and "YY" represents the presoaking time (in hours) of PA and the
Tab. 2. Chemical, physical and mechanical properties of cement

\begin{tabular}{cc}
\hline $\mathrm{CaO}(\%)$ & 64.48 \\
\hline $\mathrm{SiO}_{2}(\%)$ & 20.12 \\
\hline $\mathrm{Al}_{2} \mathrm{O}_{3}(\%)$ & 4.92 \\
\hline $\mathrm{Fe}_{2} \mathrm{O}_{3}(\%)$ & 3.57 \\
\hline $\mathrm{MgO}(\%)$ & 1.23 \\
\hline $\mathrm{SO}_{3}(\%)$ & 2.88 \\
\hline $\mathrm{Cl}^{-}(\%)$ & 0.0425 \\
\hline $\mathrm{Na}_{2} \mathrm{O} / \mathrm{K}_{2} \mathrm{O}$ & $0.24 / 0.89$ \\
\hline Loss on ignition (\%) & 1.72 \\
\hline Insoluble residue (\%) & 0.92 \\
\hline Specific gravity (g/cm $\left.{ }^{3}\right)$ & 3.14 \\
\hline Blaine fineness (cm $/ \mathrm{g})$ & 3942 \\
\hline Setting time (min) & Initial \\
\cline { 2 - 2 } & Final \\
\hline Compressive strength (MPa) \\
\hline 2 2 days & 29.6 \\
\hline 7 days & 45.8 \\
\hline 28 days & 56.1 \\
\hline
\end{tabular}

volume percent $(\%)$ of PA substituted with normal weight fine aggregates, respectively.

\subsection{Specimen preparation, curing and testing}

In order to determine the effect of PA substitution on concrete properties under various environmental conditions, compressive strength, splitting tensile strength, total shrinkage, and frost resistance tests were performed on $100 \mathrm{~mm}$ cube, $100 / 200 \mathrm{~mm}$ cylinder, $70 \times 70 \times 285 \mathrm{~mm}$ prism, and $70 \mathrm{~mm}$ cube specimens respectively. Additionally, density, ultrasonic pulse velocity (UPV) and dynamic modulus of elasticity were determined on $100 \mathrm{~mm}$ cube specimens.

All specimens, except the ones for the frost resistance test, were stored at different curing conditions (see Table 4) until testing. Among these conditions "mode A" represents the standard water curing $\left(20 \pm 2^{\circ} \mathrm{C}\right)$, "mode $\mathrm{B}$ " represents drying in air at laboratory conditions $\left(23 \pm 2^{\circ} \mathrm{C}\right.$ and $\left.50 \pm 5 \% \mathrm{RH}\right)$ and "mode C" represents drying in hot weather conditions $\left(40 \pm 2{ }^{\circ} \mathrm{C}\right.$ and $20 \pm 2 \% \mathrm{RH})$. In order to simulate hot weather conditions a laboratory type oven was used.

\subsection{Test procedure}

The specimens for shrinkage measurements were demolded $24 \mathrm{~h}$ after casting and stored at mode B and mode $\mathrm{C}$ conditions. The length changes were measured at 2, 7, 28, 56, 90 and 180 days using a comparator according to ASTM C 157 [23]. Additionally, mass loss measurements were performed at the same days. The measurements were conducted on two specimens for each concrete mixes. Density and UPV were determined according to EN 12390-7 [24] and ASTM C 597 [25] respectively at 28 days. Test specimens for each series were stored at three different conditions as shown in Table 4. Dynamic modulus of 
Tab. 3. Mix proportions and fresh concrete properties

\begin{tabular}{|c|c|c|c|c|c|c|c|c|c|c|}
\hline \multirow{4}{*}{$\begin{array}{l}\text { Mixture } \\
\text { Code }\end{array}$} & \multirow{4}{*}{$\begin{array}{c}\text { Cement } \\
(\mathrm{kg})\end{array}$} & \multirow{4}{*}{$\begin{array}{c}\text { Water } \\
(\mathrm{kg})\end{array}$} & \multirow{4}{*}{$\begin{array}{c}\text { Admixtures } \\
(\mathrm{kg})\end{array}$} & \multicolumn{4}{|c|}{ Aggregate } & \multirow{4}{*}{$\begin{array}{c}\text { Presoak } \\
\text { water }(\mathrm{kg})\end{array}$} & \multirow{4}{*}{$\begin{array}{l}\text { Slump } \\
(\mathrm{cm})\end{array}$} & \multirow{4}{*}{$\begin{array}{c}\text { Fresh } \\
\text { density } \\
\left(\mathrm{kg} / \mathrm{m}^{3}\right)\end{array}$} \\
\hline & & & & \multicolumn{3}{|c|}{ Normal weight } & \multirow{2}{*}{ Pumice } & & & \\
\hline & & & & \multirow{2}{*}{$\begin{array}{c}\text { Coarse } \\
\text { 4-16 mm }\end{array}$} & \multicolumn{2}{|c|}{ Fine } & & & & \\
\hline & & & & & $0-1 \mathrm{~mm}$ & $1-4 \mathrm{~mm}$ & $1-4 \mathrm{~mm}$ & & & \\
\hline $\mathrm{R}$ & 400 & 160 & 5.2 & 1068.3 & 414.8 & 414.8 & - & - & 19 & 2489 \\
\hline $\mathrm{P} 1-50$ & 400 & 160 & 5.2 & 1068.3 & 414.8 & 207.4 & 80.3 & 18.1 & 13 & 2369 \\
\hline P1-100 & 400 & 160 & 5.2 & 1068.3 & 414.8 & - & 160.8 & 36.2 & 15 & 2231 \\
\hline P24-50 & 400 & 160 & 5.2 & 1068.3 & 414.8 & 207.4 & 83.4 & 27.1 & 14 & 2376 \\
\hline P24-100 & 400 & 160 & 5.2 & 1068.3 & 414.8 & - & 166.8 & 54.2 & 17 & 2272 \\
\hline
\end{tabular}

Tab. 4. Exposure conditions

\begin{tabular}{|c|c|c|}
\hline \multirow{2}{*}{ Mode } & \multicolumn{2}{|c|}{ Curing conditions } \\
\hline & 0 to 24 hours & 24 hours to 28 days \\
\hline$A$ & In mold at & Water curing at $20 \pm 2{ }^{\circ} \mathrm{C}$ \\
\hline B & laboratory & $\begin{array}{c}\text { Drying in laboratory at } 23 \pm 2^{\circ} \mathrm{C} \text { and } \\
50 \pm 5 \% \mathrm{RH}\end{array}$ \\
\hline C & conditions & $\begin{array}{c}\text { Drying in oven at } 40 \pm 2{ }^{\circ} \mathrm{C} \text { and } \\
20 \pm 2 \% \mathrm{RH}\end{array}$ \\
\hline
\end{tabular}

elasticity was calculated according to the following equation:

$$
E_{d}=10^{4} \times V^{2} \times\left(\frac{\rho}{g}\right)
$$

where Ed is the dynamic modulus of elasticity $(\mathrm{MPa}), \mathrm{V}$ is the UPV $(\mathrm{km} / \mathrm{s}), \rho$ is density of the specimen $\left(\mathrm{kg} / \mathrm{dm}^{3}\right)$ and $\mathrm{g}$ is the acceleration due to gravity $\left(9.81 \mathrm{~m} / \mathrm{s}^{2}\right)$.

Compressive strength and splitting tensile strength

was determined on three $100 \mathrm{~mm}$ cube specimens according to EN 12390-3 [26] and on three 100/200 mm cylinder specimens according to EN 12390-6 [27] at 28 days respectively. These specimens, as well, were stored at mode A, mode B and mode $\mathrm{C}$ conditions.

FT cycles were conducted on three $70 \mathrm{~mm}$ cubic specimens for each mix to determine their frost resistance. In actual field practice the first FT cycle may occur as soon as the concrete is placed, therefore the cycles were started at the age of $24 \mathrm{~h}$ to simulate the actual severe environmental situations. There are a quite number of applications and standard procedures for determining the frost resistance of concrete [28-33]. In this study, specimens were first cooled at $-20 \pm 20^{\circ} \mathrm{C}$ in a deep freezer for $24 \mathrm{~h}$ and then immersed in water at $21 \pm 3^{\circ} \mathrm{C}$ for another $24 \mathrm{~h}$ to complete a single FT cycle. The procedure is similar with that applied by Laoubi et al. [33]. FT cycles were repeated until 90 days, for 45 cycles and FT resistance of the concretes was evaluated by determining the compressive strength at the end of the FT cycles.

\section{Results and Discussion}

\subsection{Total shrinkage and mass loss}

Figs. 1 and 2 show the development of total shrinkage of the concrete mixes exposed to air drying (mode B) and hot weather drying (mode $\mathrm{C}$ ) respectively. In both exposure cases the reference concrete $(\mathrm{R})$ showed higher shrinkage values. In exposure to mode $\mathrm{B}$, shrinkage of concretes tends to increase by time, even at 180 days (Fig. 1). However at mode C, shrinkage tends to end at 90 days (Fig. 2).

Moisture loss is one of the underlying causes of shrinkage. At mode $\mathrm{B}$, mass losses of concrete specimens tend to increase by drying time (Fig. 3) so as the total shrinkage. However at mode $\mathrm{C}$, specimens tend to come to equilibrium considering their mass change values (Fig. 4) at 90 days, and further shrinkage development is negligible. The substitution of normal weight sand by presoaked PA led to a reduction in shrinkage at both exposure conditions. The improvement in the shrinkage behaviour of concrete by incorporation of prewetted PA is most likely due to the internal curing effect caused by moisture release from the aggregate during drying. Among all series P1-50 and P24-50 possessed the lowest shrinkage values when exposed to mode $\mathrm{B}$ and $\mathrm{C}$ respectively. Although $100 \%$ PA substitution revealed higher shrinkage than those substituted by $50 \%$, their shrinkage values were still lower than the reference concrete $(\mathrm{R})$. Herrera et. al [8] found that the substitution of $20 \%$ normal weight sand by lightweight sand by mass led to a shrinkage reduction of 40 , 30 , and $20 \%$ at the ages of 7, 28, and 91 days, respectively. In this research P1-50 and P24-50 provided 34\% and 33\% decrease in total shrinkage at 180 days at modes $\mathrm{B}$ and $\mathrm{C}$ respectively, in comparison to the reference concrete.

\subsection{Density and UPV}

The density values, as shown in Table 5, ranged from $2496 \mathrm{~kg} / \mathrm{m}^{3}$ to $2189 \mathrm{~kg} / \mathrm{m}^{3}$. The replacement of normal weight sand by $\mathrm{PA}$ and the change in the exposure conditions from mode $\mathrm{A}$ to mode $\mathrm{C}$ resulted in a reduction in the density values, as can be seen in Fig. 5. The reference concrete $(\mathrm{R})$ had the highest density value while the lowest was measured for the P24-100 concrete exposed to mode C. 
Tab. 5. Density and UPV of concretes

\begin{tabular}{ccccccc}
\hline Mixture & \multicolumn{3}{c}{ Density $\left(\mathrm{kg} / \mathrm{m}^{3}\right)$} & \multicolumn{3}{c}{ Ultrasonic pulse velocity $(\mathrm{m} / \mathrm{s})$} \\
\cline { 2 - 7 } code & Mode A & Mode B & Mode C & Mode A & Mode B & Mode C \\
\hline R & 2496 & 2463 & 2444 & 4810 & 4780 & 4760 \\
P1-50 & 2392 & 2359 & 2326 & 4560 & 4630 & 4570 \\
P1-100 & 2236 & 2208 & 2203 & 4390 & 4530 & 4520 \\
P24-50 & 2392 & 2350 & 2336 & 4600 & 4680 & 4690 \\
P24-100 & 2251 & 2246 & 2189 & 4430 & 4600 & 4470 \\
\hline
\end{tabular}

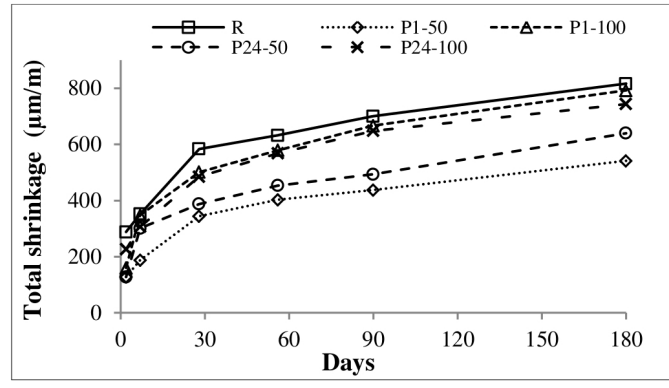

Fig. 1. Total shrinkage of concretes exposed to mode B

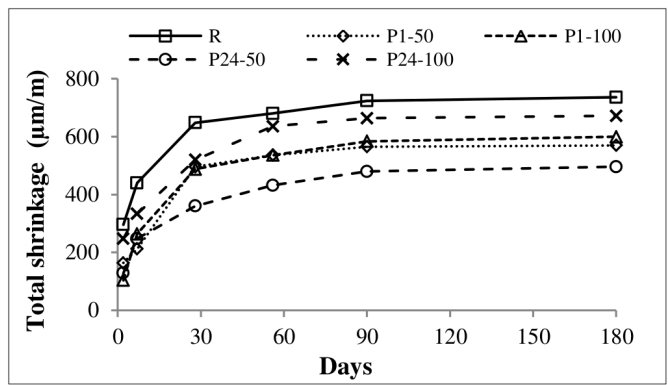

Fig. 2. Total shrinkage of concretes exposed to mode C

The UPV values of the concretes, as presented in Table 5 . ranged from $4390 \mathrm{~m} / \mathrm{s}$ to $4810 \mathrm{~m} / \mathrm{s}$; the highest value belongs to the reference concrete cured in water (mode A) and the lowest to the P1-100 concrete exposed to mode C. The substitution of PA with normal weight sand caused a reduction in the UPV; the higher the substitution resulted in a higher reduction. Whitehurst [34] has classified concretes as excellent, good, doubtful, poor and very poor for UPV values of $4500 \mathrm{~m} / \mathrm{s}$ and above, $3500-4500 \mathrm{~m} / \mathrm{s}, 3000-3500 \mathrm{~m} / \mathrm{s}, 2000-3000 \mathrm{~m} / \mathrm{s}$ and $2000 \mathrm{~m} / \mathrm{s}$, respectively. According to this classification, all produced concretes can at least be classified as good, since all measured UPV values were greater than $3500 \mathrm{~m} / \mathrm{s}$ (Fig. 6). The trend in UPV values is to increase with increasing compressive strength for all the mixtures (Fig. 77. Similar results have been obtained by other researchers [35, 36]. Strong correlations were established between the compressive strength and the UPV as shown in Fig. 7

\subsection{Strength and dynamic modulus of elasticity}

Mechanical properties of concretes at 28 days are summarized in Table 6 The compressive strength values were in the range of $74.2-45.6 \mathrm{MPa}$; where the lowest value belongs to the P1-100 mix exposed to mode $\mathrm{C}$ and the highest one to the

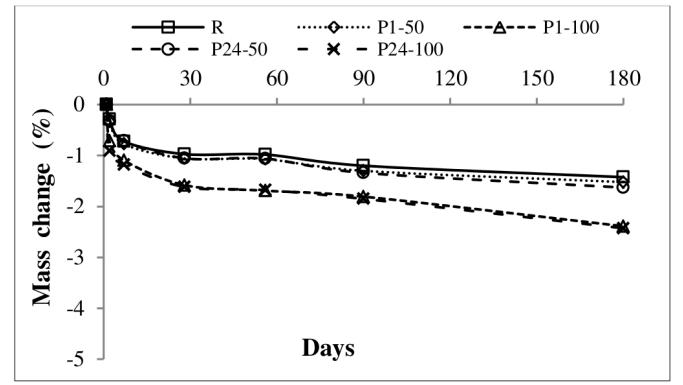

Fig. 3. Mass change of concretes exposed to mode B

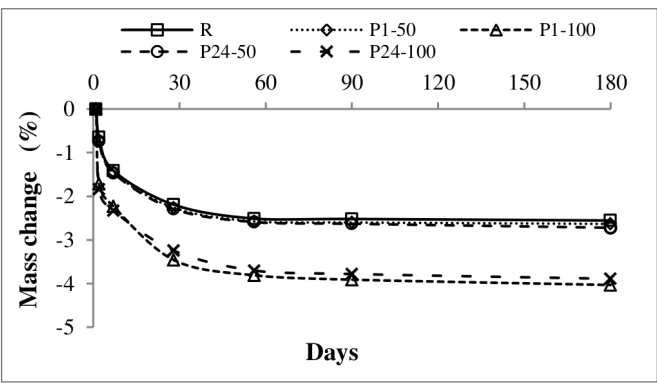

Fig. 4. Mass change of concretes exposed to mode C

reference concrete $(\mathrm{R})$ cured in water (mode A). Fig. 8 shows the change in the compressive strength of concrete with varying pumice content and presoaking time at different environmental conditions. It is clearly seen that there is a slight decrease in compressive strength with increasing PA content; the reference possessing the highest strength values for all curing conditions. It has been reported that the use of porous LWA with a lower intrinsic strength might limit the strength attained by the concrete [2]. The same findings have also been presented by several researchers [8,9].

The reduction in compressive strength can be seen in Fig. 9 where the relationship between compressive strength and PA content is displayed. However when we compare P1-100 and P24-100 series, the increase in presoak water content resulted

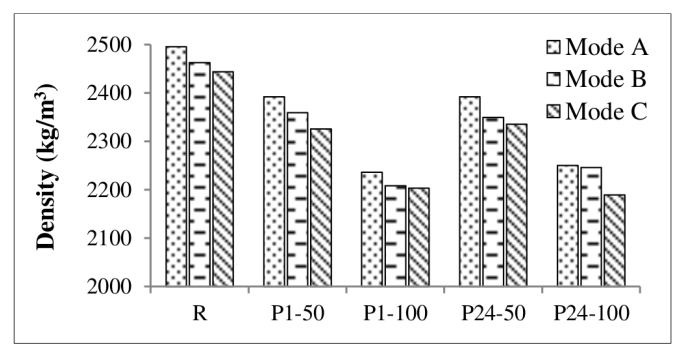

Fig. 5. Density of concretes exposed to modes A, B and C 
Tab. 6. Mechanical properties of concretes for different exposure conditions

\begin{tabular}{|c|c|c|c|c|c|c|c|c|c|}
\hline \multirow{2}{*}{ Mixture code } & \multicolumn{3}{|c|}{ Compressive strength (MPa) } & \multicolumn{3}{|c|}{ Splitting tensile strength (MPa) } & \multicolumn{3}{|c|}{ Dynamic modulus of elasticity (MPa) } \\
\hline & Mode A & Mode B & Mode C & Mode A & Mode B & Mode C & Mode A & Mode B & Mode C \\
\hline $\mathrm{R}$ & 74.2 & 71.7 & 68.5 & 4.3 & 4.2 & 4.0 & 58863 & 57362 & 56447 \\
\hline $\mathrm{P} 1-100$ & 47.4 & 47.1 & 45.6 & 3.5 & 3.6 & 3.3 & 46781 & 45985 & 43286 \\
\hline P24-50 & 62.7 & 60.6 & 60.3 & 4.8 & 4.8 & 4.3 & 53407 & 52683 & 50375 \\
\hline P24-100 & 50.5 & 50.5 & 48.6 & 3.9 & 3.9 & 3.8 & 48544 & 45742 & 43795 \\
\hline
\end{tabular}

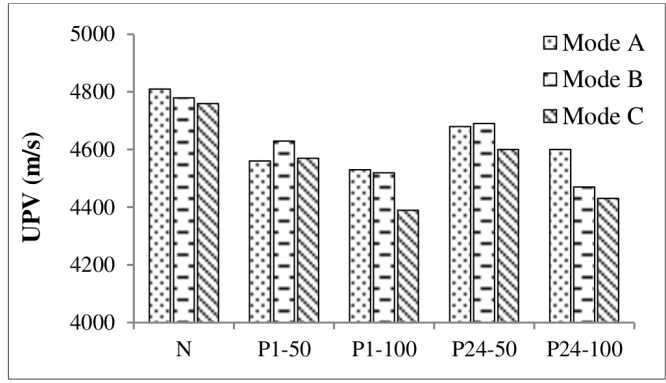

Fig. 6. UPV of concretes exposed to modes A, B and C

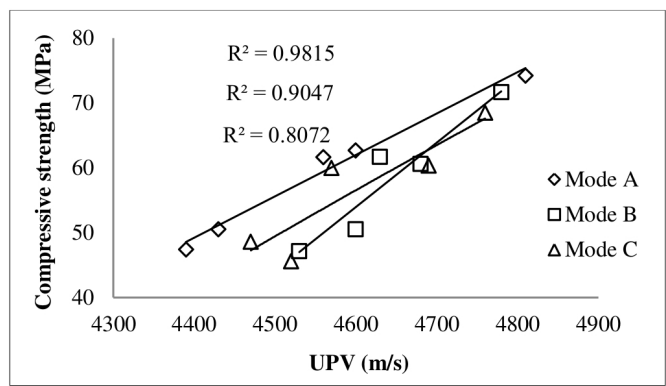

Fig. 7. Compressive strength-UPV relationship

in a slight increase in the compressive strength. Similar finding was reported by Kabay and Aköz [37] where they found that the increase in saturation degree of the LWA resulted in a higher strength. P24-100 achieved 6.5\%, 7.2\% and 6.6\% higher strength values than $\mathrm{P} 1-100$ at modes $\mathrm{A}, \mathrm{B}$ and $\mathrm{C}$ respectively. This behaviour can be attributed to the increased efficiency of the hydration due to the effective internal curing. But this trend was not observed in the samples with lower substitution ratio (P1-50 and P24-50).

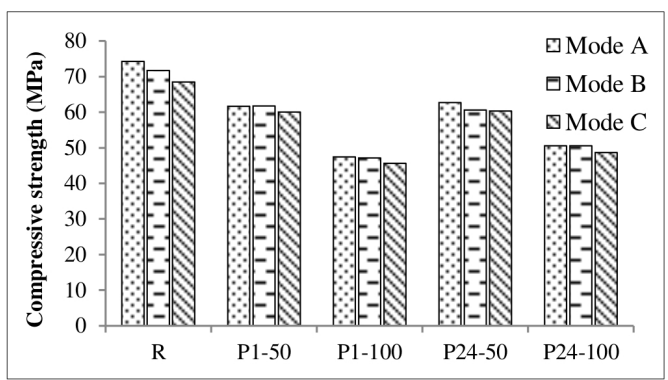

Fig. 8. Compressive strength of concretes exposed to modes A, B and C

The effect of curing conditions on compressive strength can be seen in Table 6. The compressive strength of the reference concrete $(\mathrm{R})$ decreased by $3.4 \%$ and $7.7 \%$ when exposed to mode $\mathrm{B}$ and mode $\mathrm{C}$ respectively, in comparison to that at mode

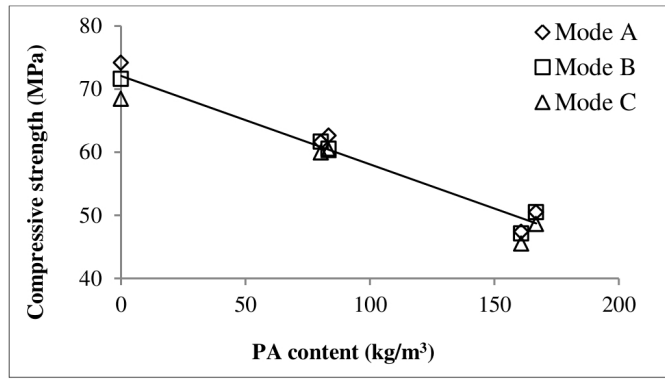

Fig. 9. Variation of compressive strength with PA content

A. The loss in the compressive strength of concrete mixes containing prewetted PA varied between $0 \%$ to $3.3 \%$ and $2.7 \%$ to $3.9 \%$ at modes $\mathrm{B}$ and $\mathrm{C}$ respectively; $\mathrm{P} 1-50$ performing the best. The worst exposure condition turned out to be mode $\mathrm{C}$ which simulates hot weather conditions, yielding the lowest compressive strength values for all concrete mixes. The results showed that the exposure conditions had a slight effect on the compressive strength, however it can be noticed that the mixes incorporating PA are less affected by changing the curing conditions from mode $\mathrm{A}$ to mode $\mathrm{C}$.

The splitting tensile strength values of concretes are presented in Fig. 10 . The substitution of $50 \%$ of fine aggregate by PA resulted in an increase in the tensile strength of concrete. The increase in tensile strength, particularly for P24-50 specimens, might be attributed to the higher bonding of aggregates and cement paste due to the better hydration caused by internal curing effect. The increase in the substitution ratio, on the other hand, resulted in drops. As in compressive strength, the increase in PA presoaking time from $1 \mathrm{~h}$ to $24 \mathrm{~h}$ contributed to the splitting tensile strength values; P24-50 possessed the highest values at all exposure modes. When we consider the reference concrete $(\mathrm{R})$, the tensile strength slightly decreased by the change of the exposure mode in the order of A, B and C. However, when we consider the concrete mixes with PA, curing in air (mode B) did not adversely affect the tensile strength. The worst exposure condition, as in the compressive strength, turned out to be mode C.

The dynamic modulus of elasticity values of concretes are shown in Table 6 As expected the modulus of elasticity is reduced by the inclusion of PA and the reference concrete (R) possessed the highest values at all exposure conditions. 


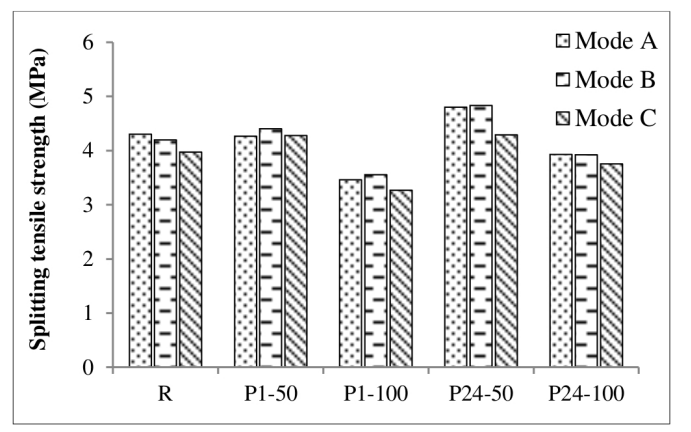

Fig. 10. Tensile strength of concretes exposed to modes A, B and C

\subsection{Frost resistance}

The relative residual strengths of concretes, at the end of the FT cycles, are presented in Fig. 11. According to Fig. 11, it can be noticed that the loss in strength was higher in the concrete mixes with $100 \%$ PA. While the reference (R) lost about $14 \%$ of its strength; P1-50 and P24-50 lost only about $2 \%$ of their strength after the FT cycles. Litvan and Sereda [38] and Kuboyama et al. [39] indicated that porous aggregates can be used to increase the frost resistance of concrete. The results obtained in our study also confirm this statement except for the concretes with $100 \%$ PA substitution. The highest deterioration was observed in P24-100 series, revealing a reduction of 34\% in its compressive strength. This might be attributed to the higher amount of presoaked water content within the PA. This amount of water might possibly have caused an increased $\mathrm{w} / \mathrm{c}$ ratio at the transition zone and caused excessive deteriorations during the FT cycles. The results showed that substituting $50 \%$ of fine aggregate with PA enhanced the FT resistance of concrete, however the increase in the substitution ratio had an adverse effect.

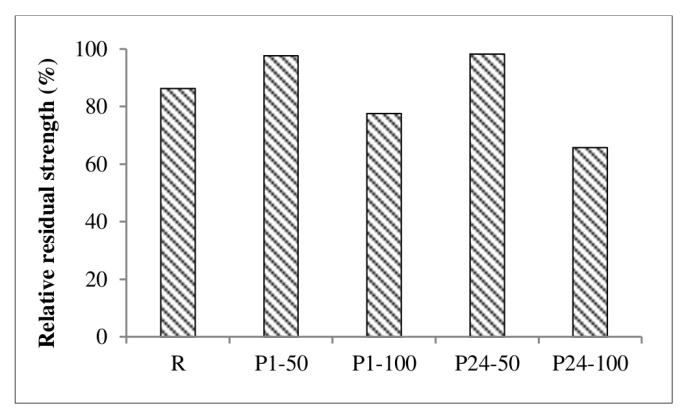

Fig. 11. Relative residual strength of concretes after FT cycles

\section{Conclusions}

Based on the test results of this study, the following conclusions may be drawn:

1 A reduction in compressive strength was observed when normal weight fine aggregate is replaced by pumice aggregate; the higher the replacement ratio resulted in higher reduction.

2 The effect of curing conditions considered in this research did not have a significant effect on the strength development of concretes; however addition of presoaked pumice aggregate decreased the strength drops when the curing conditions changed from mode $\mathrm{A}$ to mode $\mathrm{C}$, in comparison to the reference concrete.

3 Substituting $50 \%$ of fine aggregate with pumice aggregate resulted in a slight increase in the splitting tensile strength, compared to the reference, at all exposure modes. As in compressive strength, the increase in presoaking time from $1 \mathrm{~h}$ to $24 \mathrm{~h}$ contributed to the splitting tensile strength values and P24-50 possessed the highest tensile strength at all exposure modes.

4 Pumice inclusion provided a decrease in total shrinkage. P150 and P24-50 concrete mixes possessed the lowest total shrinkage values, when exposed to mode $\mathrm{B}$ and $\mathrm{C}$ respectively, providing more than $30 \%$ reduction in shrinkage, in comparison to the reference.

5 Frost resistance of the concretes was enhanced with the use of presoaked pumice aggregate at $50 \%$ replacement ratio; losing only $2 \%$ of their compressive strengths, where the reference lost $14 \%$.

\section{Acknowledgement}

This research was carried out in the Faculty of Civil Engineering at Yildiz Technical University. The authors would like to acknowledge the laboratory staff for their helps in concrete productions.

\section{References}

1 Powers TC, A Discussion of Cement Hydration in Relation to the Curing of Concrete, Proceedings of the Highway Research Board, 27, (1947), 178-188.

2 Paul Á, Lopez M, Assessing lightweight aggregate efficiency for maximizing internal curing performance, ACI Materials Journal, 108, (2011), 385-393, DOI $10.14359 / 51683111$

3 Espinoza-Hijazin G, Paul Á, Lopez M, Concrete containing natural pozzolans: new challenges for internal curing, Journal of Materials in Civil Engineering, 24, (2012), 981-988, DOI 10.1061/(ASCE)MT.19435533.0000421

4 Neville AM, Properties of concrete, John Wiley \& Sons, 1996, ISBN ISBN 978-0470235270.

5 Cusson D, Hoogeveen T, Internal curing of high-performance concrete with pre-soaked fine lightweight aggregate for prevention of autogenous shrinkage cracking, Cement and Concrete Research, 38, (2008), 757-765, DOI 10.1016/j.cemconres.2008.02.001

6 Kockal N, Turker F, Effect of environmental conditions on the properties of concretes with different cement types, Construction and Building Materials, 21, (2007), 634-645, DOI 10.1016/j.conbuildmat.2005.12.004

7 Philleo RE, Concrete science and reality, Materials Science of Concrete II, In: Skalny J, Mindess S (eds.), Materials Science of Concrete II, American Ceramic Society; Westerville, USA, 1991, pp. 1-8. Vol. B, ISBN: 9780944904374.

8 Durán-Herrera A, Aitcin P-C, Petrov N, Effect of saturated lightweight sand substitution on shrinkage in $0.35 \mathrm{w} / \mathrm{b}$ concrete, ACI Materials Journal, 104, (2007), 48-52, DOI 10.14359/18494

9 Liu X, Zhang $\mathbf{M}-\mathbf{H}$, Permeability of high-performance concrete incorporating presoaked lightweight aggregates for internal curing, Magazine of Concrete Research, 62, (2010), 79-89, DOI doi:10.1680/macr.2008.62.2.79

10 Akcay B, Tasdemir MA, Effects of distribution of lightweight aggregates on internal curing of concrete, Cement and Concrete Research, 32, (2012), 611-616, DOI 10.1016/j.cemconcomp.2010.07.003 
11 Zhutovsky S, Kovler K, Effect of internal curing on durability-related properties of high performance concrete, Cement and Concrete Research, 42, (2012), 20-26, DOI 10.1016/j.cemconres.2011.07.012

12 Henkensiefken R, Bentz D, Nantung T, Weiss J, Volume change and cracking in internally cured mixtures made with saturated lightweight aggregate under sealed and unsealed conditions, Cement and Concrete Research, 31, (2009), 427-437, DOI 10.1016/j.cemconcomp.2009.04.003

13 Henkensiefken R, Castro J, Bentz D, Nantung T, Weiss J, Water absorption in internally cured mortar made with water-filled lightweight aggregate, Cement and Concrete Research, 39, (2009), 883-892, DOI 10.1016/j.cemconres.2009.06.009

14 Browning J, Darwin D, Reynolds D, Pendergrass B, Lightweight aggregate as internal curing agent to limit concrete shrinkage, ACI Materials Journal, 108, (2011), 638-644, DOI 10.14359/51683467

15 Bentur A, Igarashi S-I, Kovler K, Prevention of autogenous shrinkage in high-strength concrete by internal curing using wet lightweight aggregates, Cement and Concrete Research, 31, (2001), 1587-1591, DOI 10.1016/S0008-8846(01)00608-1

16 Castro J, Spragg R, Weiss J, Water absorption and electrical conductivity for internally cured mortars with a w/c between 0.30 and 0.45 , Journal of Materials in Civil Engineering, 24, (2012), 223-231, DOI 10.1061/(ASCE)MT.1943-5533.0000377

17 Jensen OM, Hansen PF, Water-entrained cement-based materials: I. Principle and theoretical background, Cement and Concrete Research, 31, (2001), 647-654, DOI 10.1016/S0008-8846(01)00463-X

18 Craeye B, Geirnaert M, De Schutter G, Super absorbing polymers as an internal curing agent for mitigation of early-age cracking of highperformance concrete bridge decks, Construction and Building Materials, 25, (2011), 1-13, DOI 10.1016/j.conbuildmat.2010.06.063

19 Mechtcherine V, Dudziak L, Schulze J, Internal Curing by Super Absorbent Polymers (SAP) - Effects on material properties of self-compacting fibre-reinforced high performance concrete, International RILEM Conference on Volume Changes of Hardening Concrete: Testing and Mitigation, In: Jensen OM, Iványi M, Kovács N, Vigh LG (eds.), International RILEM Conference on Volume Changes of Hardening Concrete: Testing and Mitigation, RILEM Publications SARL; Lyngby, Denmark, 2006, pp. 87-96, DOI 10.1617/2351580052.010 ISBN: 2-35158-004-4.

20 Suzuki M, Meddah MS, Sato R, Use of porous ceramic waste aggregates for internal curing of high-performance concrete, Cement and Concrete Research, 39, (2009), 373-381, DOI 10.1016/j.cemconres.2009.01.007

21 Fakitsas CG, Papakonstantinou PEA, Kiousis PD, Savva A, Effects of recycled concrete aggregates on the compressive and shear strength of highstrength self-consolidating concrete, Journal of Materials in Civil Engineering, 24, (2012), 356-361, DOI 10.1061/(ASCE)MT.1943-5533.0000397

22 Bentz DP, Snyder KA, Protected paste volume in concrete - Extension to internal curing using saturated lightweight fine aggregate, Cement and Concrete Research, 29, (1999), 1863-1867, DOI 10.1016/S00088846(99)00178-7

23 ASTM C 157, Standard test method for length change of hardened hydrauliccement mortar and concrete, ASTM International; West Conshohocken, PA, USA, 2008.

24 EN 12390-7, Testing hardened concrete - Part 7: Density of hardened concrete, European Standard; London, UK, 2009.

25 ASTM C 597, Standard test method for pulse velocity through concrete, ASTM International; West Conshohocken, PA, USA, 2009.

26 EN 12390-3, Testing hardened concrete - Part 3: Compressive strength of test specimens, European Standard; London, UK, 2009.

27 EN 12390-6, Testing hardened concrete - Part 6: Tensile splitting strength of test specimens, European Standard; London, UK, 2009.

28 ASTM C 666, Standard test method for resistance of concrete to rapid freezing and thawing, ASTM International; West Conshohocken, PA, USA, 2003.
29 CEN/TR 15177, Testing the freeze-thaw resistance of concrete - Internal structural damage, Comité Européen de Normalisation; Brussels, Belgium, 2006.

30 CEN/TS 12390-9, Testing hardened concrete - Part 9: Freeze-thaw resistance - Scaling, Comité Européen de Normalisation; Brussels, Belgium, 2006.

31 Wenting $\mathbf{L}$, Wei $\mathbf{S}$, Jinyang $\mathbf{J}$, Damage of concrete experiencing flexural fatigue load and closed freeze/thaw cycles simultaneously, Construction and Building Materials, 25, (2011), 2604-2610, DOI 10.1016/j.conbuildmat.2010.12.007

32 Kucharczyková B, Kersner Z, Pospíchal O, Misák P, Danek P, Schmid $\mathbf{P}$, The porous aggregate pre-soaking in relation to the freeze-thaw resistance of lightweight aggregate concrete, Construction and Building Materials, 30, (2012), 761-766, DOI 10.1016/j.conbuildmat.2011.12.067

33 Laoubi K, El-Salakawy E, Benmokrane B, Creep and durability of sandcoated glass FRP bars in concrete elements under freeze/thaw cycling and sustained loads, Cement and Concrete Composites, 28, (2006), 869-878, DOI $10.1016 /$ j.cemconcomp.2006.07.014

34 Whitehurst EA, Soniscope tests concrete structures, Journal of the American Concrete Institute, 4, (1951), 443-444, DOI 10.14359/12004

35 Trtnik G, Kavcic F, Turk G, Prediction of concrete strength using ultrasonic pulse velocity and artificial neural networks, Ultrasonics, 49, (2009), 53-60, DOI $10.1016 / \mathrm{j}$.ultras.2008.05.001

36 Uysal M, Yılmaz K, Effect of mineral admixtures on properties of selfcompacting concrete, Cement and Concrete Composites, 33, (2011), 771776, DOI 10.1016/j.cemconcomp.2011.04.005

37 Kabay N, Aköz F, Effect of prewetting methods on some fresh and hardened properties of concrete with pumice aggregate, Cement and Concrete Composites, 34, (2012), 503-508, DOI 10.1016/j.cemconcomp.2011.11.022

38 Litvan GG, Sereda PJ, Particulate admixture for enhanced freeze-thaw resistance of concrete, Cement and Concrete Composites, 8, (1978), 53-60, DOI 10.1016/0008-8846(78)90057-1

39 Kuboyama K, Nakano S, Sukekiyo M, Improvement of freeze-thaw resistance of concrete by addition of porous fine aggregates, In: Conference on frost damage to concrete; Hokkaido Dev Bureau, Hokkaido, 1988, pp. 107112. 